\title{
Pienwszy krok w kierunku „smart project”, czyli inwentaryzacja stanu istniejącego budynku w standardzie BIM
} First step in the direction of a "smart project" -
the surveying of the extant state of a building in the BIM standard

\begin{abstract}
Streszczenie
Dzięki wielu korzyściom płynącym z wdrażania najnowszych technologii informatycznych do architektury i budownictwa BIM nieuchronnie staje się standardem nowoczesnego projektowania. Technologia BIM dotyczy również etapu inwentaryzacji budynków.

Kolejność prac przy inwentaryzacji w standardzie BIM na podstawie skanowania laserowego jest następująca: Pierwszą czynnością są pomiary tachimetryczne. Następnie $w$ wyniku skanowania laserowego uzyskujemy tzw. chmury punktów, z których generowane są tzw. ortofotoplany. Na ich podstawie budowany jest wirtualny model budynku. Po naniesieniu wymiarowania i opisów $z$ modelu 3D (4D+5D) można wygenerować rzuty, przekroje $i$ elewacje oraz różnego typu zestawienia.
\end{abstract}

\begin{abstract}
Thanks to the numerous benefits gained from the implementation of the latest information technologies in architecture and construction, BIM is unavoidably becoming the standard of modern design. BIM Technology also applies to the stage of surveying a building.

The sequence of work when surveying a building in the BIM standard on the basis of laser scanning is as follows: The first task to be performed is tachymetric measurement. Afterwards, as a result of laser scanning, we obtain so-called point clouds, from which so-called orthophotoplans are generated. Based on these plans, a virtual model of a building is generated. After applying dimensions and annotation from the 3D (4D+5D) model, we can generate floor plans, cross-sections and elevations, as well as various types of schedules.
\end{abstract}

Słowa kluczowe: tachimetria, skanowanie laserowe, chmura punktów, ortofotoplan, model wirtualny budynku Keywords: tachymetry, laser scanning, point cloud, orthophotoplan, virtual model of the building

\section{WPROWADZENIE}

BIM (ang. Building Information Modeling) ${ }^{1,2}$ to w dosłownym przekładzie "modelowanie informacji o budynku", co oznacza tworzenie, przy pomocy odpowiedniego oprogramowania, ogromnej bazy danych, dokładnie definiującej każdą część budynku (konstrukcję, materiały i ich właściwości, wyposażenie, itp.) i uporządkowanej $w$ trójwymiarowej przestrzeni w postaci wirtualnego modelu 3D. Projekt w standardzie BIM powstaje przy użyciu trójwymiarowych obiektów, takich jak ściany, stropy, dachy, sufity, okna, drzwi, itd., którym, poza wymiarami geometrycznymi, nadawane są odpowiednie parametry (właściwości fizyczne, techniczne, itp.). Charakterystycznym wyróżnikiem projektowania w programach wspomagających projektowanie w standardzie BIM jest przesunięcie głównego nakładu pracy na wczesne fazy procesu projektowego, dzięki czemu możliwości wpływania na efektywność są największe, przy najniższych kosztach i najmniejszych trudnościach z tym związanych ${ }^{3}$.

\section{INTRODUCTION}

BIM (Building Information Modelling) ${ }^{1,2}$ is the creation of an immense database that precisely defines every part of a building (structure, materials and their properties, furnishings, etc.) in an ordered, three-dimensional space in the form of a 3D virtual model, using appropriate software. A design in the BIM standard is developed using threedimensional objects, such as walls, floor slabs, roofs, ceilings, windows, doors, etc., which, apart from geometric dimensions, are assigned appropriate parameters (physical and technical properties, etc.). What is distinct about designing in BIMstandard computer aided design software is the shift of the main workload to the early phases of the design process, thanks to which the possibility of affecting effectiveness is the greatest, while the costs and the associated difficulties are the lowest ${ }^{3}$. Design in the BIM standard also includes the surveying of existing buildings. The difference between traditional building surveying and surveying 
Projektowanie w standardzie BIM obejmuje również inwentaryzacje architektoniczno-budowlane budynków istniejących. Różnica pomiędzy inwentaryzacją tradycyina a inwentaryzacją w standardzie BIM jest analogiczna jak w przypadku projektów nowych budynków:

- inwentaryzacja tradycyjna wykonana jest na podstawie obmiarów w postaci zestawu płaskich rzutów, przekrojów i widoków elewacyjnych

- inwentaryzacja w standardzie BIM wykonywana jest na podstawie skanowania laserowego 3D w postaci wirtua nego modelu budynku ze sparametryzowanymi elementami i zestawieniami

Zasady $\mathbf{i}$ kolejność prac przy inwentaryzacji w standardzie BIM przedstawiono na przykładzie zabytkowego budynku V Liceum Ogólnokształcącego im. Augusta Witkowskiego w Krakowie - jednego z najbardziej renomowanych liceów w Polsce. Inwentaryzacja całego budynku w standardzie BIM została rozpoczęta w maju $2018 \mathrm{r}$. ze względu na planowana adaptacje poddaszy nad budynkiem na cele użytkowe. Około 10 lat temu jedno ze skrzydeł budynku było zinwentaryzowane w tradycyjnej technologii CAD 2D ze względu na budowę zewnętrznej windy dla potrzeb osób niepełnosprawnych. Dało to możliwość porównania jakości inwentaryzacji w standardzie BIM z inwentaryzacją wykonaną tradycyjnie.

\section{TACHIMETRIA}

Pierwszą czynnością przy sporządzaniu inwentaryzacji w standardzie BIM powinny byc pomiary ta zwalają na ustawienie w przestrzeni 3D charakterystycznych punktów referencyjnych budynku, z odniesieniem do osnowy geodezyjnej terenu.

Tachimetria to geodezyjna metoda szybkich pomiarów sytuacyjno-wysokościowych w terenie, która ma na celu wyznaczenie wspótrzędnych i wysokości wybranych punktów (w tym przypadku charakterystycznych punktów budynku) w przyjetym układzie odniesienia ${ }^{4}$. Polega ona na jednoczesw odległości do wybranych szczegółów terenowych. Pomiary tachimetryczne przeprowadzane są przy użyciu teodolitu połączonego $z$ tachimetrem. Dostępne są dwa rodzaje teodolitów - modele z optycznym systemem odczytowym i instrumenty elektroniczne. Te pierwsze charakteryzuje przede wszystkim prostota budowy i niezawodność. Nie wymagają zasilania i można ich używać praktycznie w każdej sytuacji na placu budowy. $Z$ kolei teodolity elektroniczne pozwalaja dużo szybciej wykonywać pomiary, głównie dlatego, że odczyty mierzonych kątów poziomych i pionowych wyświetlane są od razu na ekranie instrumentu. Teodolity elektroniczne mogą występowac w kilku opcjach - rekomendowane są modele $z$ modulem laserowym, który wyświetla plamkę i $w$ ten sposób przyspiesza celowanie (obserwator nie musi patrzeć w okular lunety, gdyż wyświetlana plamka laserowa może służyć do ustawiania dalmierza na widoczny punkt). Dodatkowym modułem nowoczesnego teodolitu elektronicznego jest tachimetr, czyli instrument mierzący oprócz kątów także odległości, dzięki czemu sprzęt pomiarowy ma dużo większe możliwości praktyczne. in the BIM standard is analogous as in the case of designs of new buildings:

- Tadional surveying is performed on the basis of measurements in the form of a set of two dimensional floor

- Surveying in the BIM standard is performer on the basis of $3 D$ laser scanning in the form of a virtual model of a building with parameterised elements and schedules.

The precepts and sequence of work on building been presented on the example of the historica building of the August Witkowski V High School in Krakow-one of the most renowned high school in Poland. The survey of the entire building in the BIM standard was started in May 2018 due to the planned adaptation of the attics above the buildings for utilitarian purposes. Around 10 years ago ing traditional 2D CAD technology due to the construction of an external elevator for disabled persons. This made it possible to compare the quality of BIM-standard survey with a traditional one.

\section{TACHYMETRY}

The first task when performing a building survey in chymetric measurements, which make it possible to set up distinct reference points of a building in a $3 \mathrm{D}$ space, with a reference to the geodetic network of the terrain.

Tachymetry is a surveying method of performing rapid measurements on-site, which is meant to de-
termine the coordinates and elevation of selected points (in this case the distinct points of selected within the adopted frame of references. It is based on the simultaneous measurement of directions, vertical and horizontal angles, as well as the distances to a selection of elements of the terrain. Tachymetric measurements are performed using a theodolite combined with a tachymeter. Two optic readings system and electronic instruments The former are primarily characterised by structural simplicity and reliability. They do not require power and can be used in practically any situatio on a construction site. Electronic theodolites, turn, make it possible to perform measurements the vertical and horizontal angles are immediately displayed on the instrument's screen. Electronic theodolites can come in a number of options-the recommended models feature a laser module, which displays a dot and thus improves targeting time (the observer does not need to look down the scope, as the laser dot can be used to aim the Another module of the modern electronic theodolite is the tachymeter, which is an instrument that apart from measuring angles, also measures distance, thanks to which the measurement device has much greater practical potential.

\section{LASER SCANNING}

The most important stage of a BIM building surexterior of a building and its immediate surround

\section{SKANOWANIE LASEROWE}

chimetrycznych następuje najważniejszy etap inwentaryzacji BIM, jakim jest skanowanie laserowe wnętrza i zewnętrza budynku oraz najbliższego otoczenia. Skanowanie laserowe to innowacyjna metoda wykonywania inwentaryzacji za pomocą specjalistycznej aparatury pomiarowej. Technologia ta znacznie skraca czas wykonywania inwentaryzacij nawet najbardziej wymagajacych obiektów. Metoda laserowej inwentaryzacii $3 \mathrm{D}$ cechuje bardzo duz Metoda laserowej inwentaryzacji 3D cechuje bardzo duż szczegółowość i dokładność, spełniaj

najbardziej wymagającego inwesto

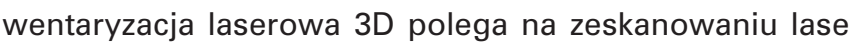
rem działającym w 3 płaszczyznach otoczenia i wszystkich elementów znajdujących się $w$ jego zasięgu. Zasięg najpopularniejszych skanerów FARO wynosi od 70 do 120 metrów $z$ jednego stanowiska pracy. $W$ trakcie pomiaru używanych jest od kilku do kilkudziesięciu stanowisk, w zależności od stopnia skomplikowania i rozmiarów skanowanego obiektu. Jednocześnie ze skanowaniem wykonywane są zdjęcia, któe dają możliwość przyporządkowania charakterystycznych punktów do powierzchni. Technologia inwentaryzacii 3D daje pełen obraz ksztattu i rozmiaru skanowanego obiektu. Przy wykorzystaniu chmury punktów, możliwe jest obcky. pry wykorystaniu chmury punktow, moźlwe jest odczytanie dowolnych wymiarow juz po opuszczeniu miejsca pomiarów bez konieczności obecności na miejscu. Dokładnośc z jaką wykonuje się pomiary, czyli standardowo $2 \mathrm{~mm}$ jest absolutnie nieosiągalna dla tradycyjnych metod pomiarowych.

W inwentaryzacji budynku V LO w Krakowie zastosowano nowy, niezwykle mobilny skaner laserowy Focus S70 firmy FARO, który umożliwia szybkie, proste i dokładne pomiary złożonych obiektów i budynków ${ }^{5}$. Skaner rejestruje elewacje, złożone konstrukcje, więźbę dachową, instalacje, itp. dostarczając realistyczne i szczegółowe wyniki skanowania przy zasiegu $70 \mathrm{~m}$ na skan. Wbudowany 8-megapikselowy apara HDR bez trudu rejestruje szczegółowy obraz, oferując nat DDR bez trudu reju runkach oświetlenia.

Najważnieisze zalety skanowania laserowego sa nastepujace

Najważniejsze zalety skanowania laserowego są następujące ryzacji,

- wyjatkowo wysoka precyzja pomiarów przestrzeni w 3 wymiarach $-z$ dokładnością do $2 \mathrm{~mm}$

zasięg skanowania do $120 \mathrm{~m}$

możliwość wykonywania pomiarów w miejscach trudno dostępnych i $w$ trakcie prowadzenia robót

bezinwazyjność pomiarów

pełna cyfrowość pomiaru - $w$ dowolnym momencie bez wychodzenia w teren można odczytać potrzebne wymiary wykorzystując jedynie plik komputerowy

możliwość sporządzania przestrzennej dokumentacj technicznej obiektu - rysunki 2D, 3D, filmy, wirtualne spacery

niższe koszty - szybkość i kompletność pomiarów przekłada się na obniżenie kosztow w stosunku do tradycyjnych metod inwentaryzacji - szczególnie dotyczy to skomplikowanych obiektów z dużą ilością detali historycznych. ings, takes place after the performance of tachymetric measurements. Laser scanning is an innovative method of performing a building survey using spely reduces the time of performing bunology greaton even the most demanding structures. The 3D Iaser scanning method is characterised by a very hig precision and level of detail, which meets the expectations of even the most demanding developer. $3 \mathrm{D}$ laser building surveying is based on scanning ine surroundings and all of the elements that are The range of the most popular FARO scanners is between 70 to 120 metres from a single workstation. During the measurements, between several to several dozen workstations are used, depending on the level of complication and the size of the structure being scanned. Photographs are taken at the same ine as the scan is performed, making it possible to nology provides a complete image of the shingechsize of the scanned structure. When using the point cloud it is possible to read any and all dimension even after leaving the measurement site without the necessity of being present there. The precision with which the measurements are performed, which is traditional measurement metethely

During the surveying of the $\mathrm{V}$ High School in $\mathrm{Kra}$ kow, a new, highly mobile laser scanner was usedthe Focus $\mathrm{S70}$ by FARO-which makes fast, simple and precise measurements of complex building and structures possible ${ }^{5}$. The scanner records facades, complicated structures, roof trusses, instalning results with a range of up to $70 \mathrm{~m}$ per scan. The inbuilt 8-megapixel HDR camera easily registers detailed images, offering a natural colourfu overlay for the scanning data in difficult lighting conditions,

The most important benefits of laser scanning are

Speed-laser scanning reduces the time necessary to perform the survey by several times,

- An exceptionally high precision of the measuretolerance,

- The possibility of performing measurements in hard-to-reach places, as well as during the performing of construction work,

- The measurements are fully digital-at any given moment, without going to the site, we can read the required dimensions using only a computer file, - The ability to develop a spatial technical docu-
mentation of a structure-2D drawings, 3D, vidmentation of a struch
eos, virtual walks,

- Lower costs-the speed and completeness of the measurements results in a lowering of costs particularly applies to complicated structures with a large amount of historical details.

\section{POINT CLOUDS}

The product of a laser scan is a file with a three
dimensional image in the form of a so-called point cloud 6 . The point cloud is a multi-millio set of points constituting a geometric representa- 


\section{CHMURY PUNKTÓW}

Efektem skanowania laserowego są pliki z przestrzennym zdjęciem w postaci tzw. chmury punktów ${ }^{6}$. Chmura punktów to wielomilionowy zbiór punktów stanowiacy geometryczną reprezentację skanowanego obiektu. Każdy z punktów ma współrzędne XYZ oraz parametr intensywności odbicia. Pozyskana ze skanowania chmura punktów posiada skale, a więc od razu można wykonywać na niej pomiary bez potrzeby wpasowania.

Należy zwrócić uwagę, że technika skanowania laserowego przysparza nierzadko problemy w interpretacii danych ze skanrzys a jej przewaga polega na bardzo krótkm czasie poska-

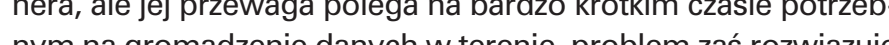
sporzagrom wraz ze anych wien o, problem zas rozwiązuje sporząlzan wraz ze skych we filtrowy filtrowywa w celuzmniejszenia wymiarów plików. tion of the scanned object. Each point has XYZ coordinates and a reflection intensity parameter. The point cloud obtained through scanning has a scale, which means that theasurements can be for any adjustments.

It should be noted that laser scanning technology sometimes causes problems in the interpretation of the data from the scanner, however, its advantage is based on the very short time that is required to gather data on-site, while the problem is that is being prepared along with the scan. Point clouds, initially at a high resolution, are filtered in order to reduce file size.

\section{ORTHOPHOTOPLANS} Based on a three-dimensional point cloud, through
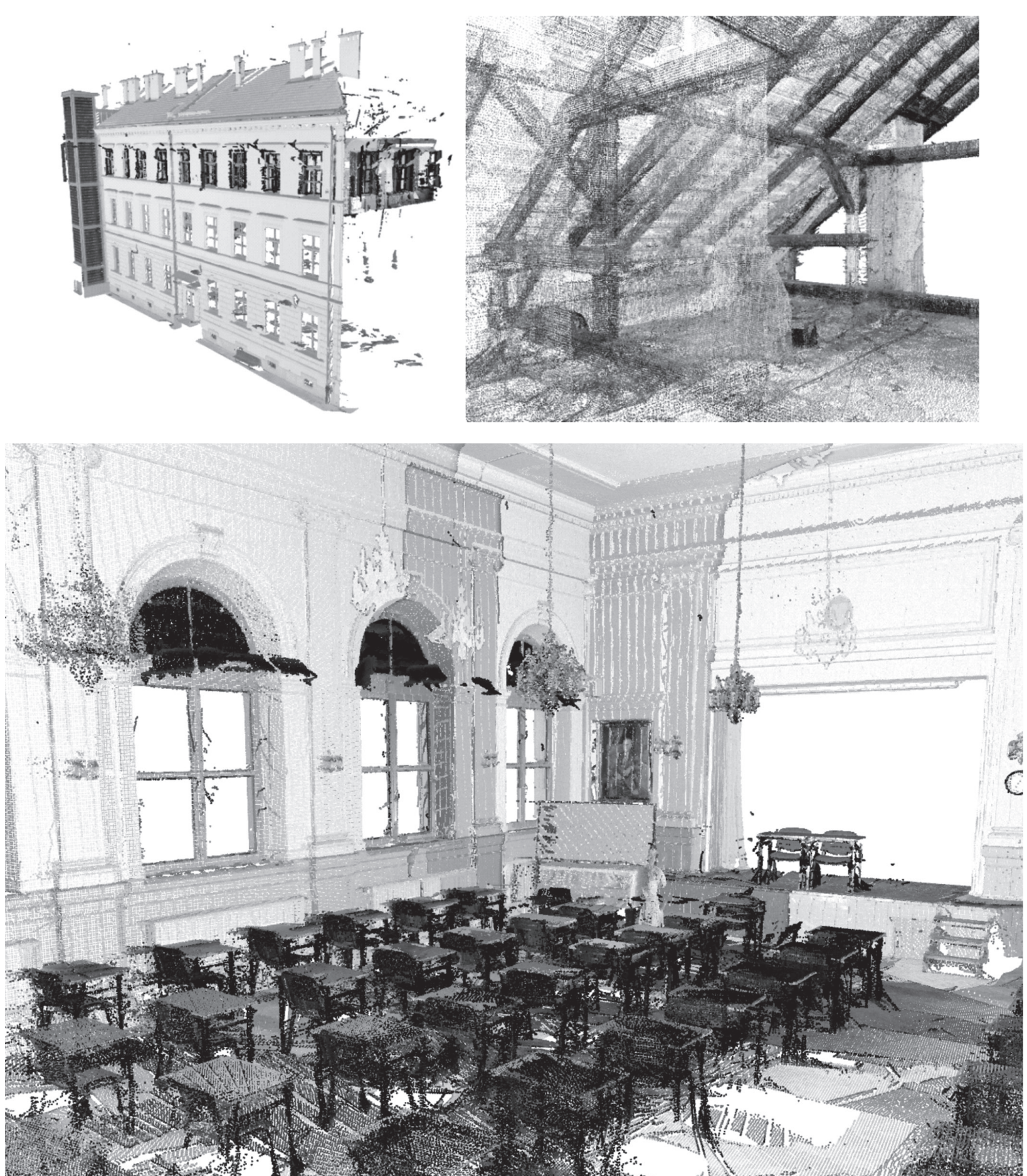

ORTOFOTOPLANY

Na podstawie trojwymiarowej chmury punktów, w procesie tzw. ortorektyfikacji generowane sa ortofotoplany, czyli płaskie rzuty, przekroje i widoki elewacyjne w układzie płaskich współrzeednych prostokątnych, ustawione odpowiednio w przestrzeni 3D.

Ortorektyfikacja to proces przetwarzania obrazów źródłowych (zdję́ fotogrametrycznych) którego celem jest uzyskanie obrazu, jaki powstatby przy rzutowaniu ortogonalnym na lipsoide odi pow mówiąc jest to zamiona rzutu środkowego na ortogonalny polegająca na polegająca r W stosunku do obrazu dr
skim odwzorowaniu.

\section{MODEL WIRTUALNY BUDYNKU}

Na podstawie ortofotoplanów budowany jest model wirtualny budynku, który w zależności od potrzeb może być sparametryzowany i powiazany z baza danych. Parametryzacja polega w pierwszym rzędzie na wyodrębnieniu charakterystycznych części budynku (ściany, stropy, belki, okna i drzw itd.) oraz na przypisaniu do poszczególnych elementów budynku ich cech fizycznych (ściany ceglane, więźba dachowa drewniana, itd.).

Wykonanie na podstawie chmur punktów i ortofotoplanów modelu wirtualnego budynku jest etapem najbardziej pracochłonnym i z perspektywy inwestora kosztownym, jednak jakość i przydatność do dalszych prac projektowych model wirtualnego 3D jest absolutnie nieporównywalna z tradycyjna dokumentacja.

W przypadku inwentaryzacji budynku V LO modelowanie zostało wykonane w programie ArchiCAD v.21. Inwentaryzacja w standardzie BIM jest spójna z modelem budynku na etapie projektowym - prace projektowe prowadzone sa na tym samym pliku z wirtualnym modelem budynku. Modut programu Przebudowa umożliwia przypisanie do każdego elementu wirtualnego modelu statusu istniejacy / do wyburzenia / uowoprojektowany. Pozwala to pracować z różnymi etapa

II. 2. Rzut środkowy z radialnymi przesunieciami i skorygowany rzut ortogonalny (oprac. aut.)
III. 2. Perspective projection with radial shifts and a corrected orthogonal projection (original work
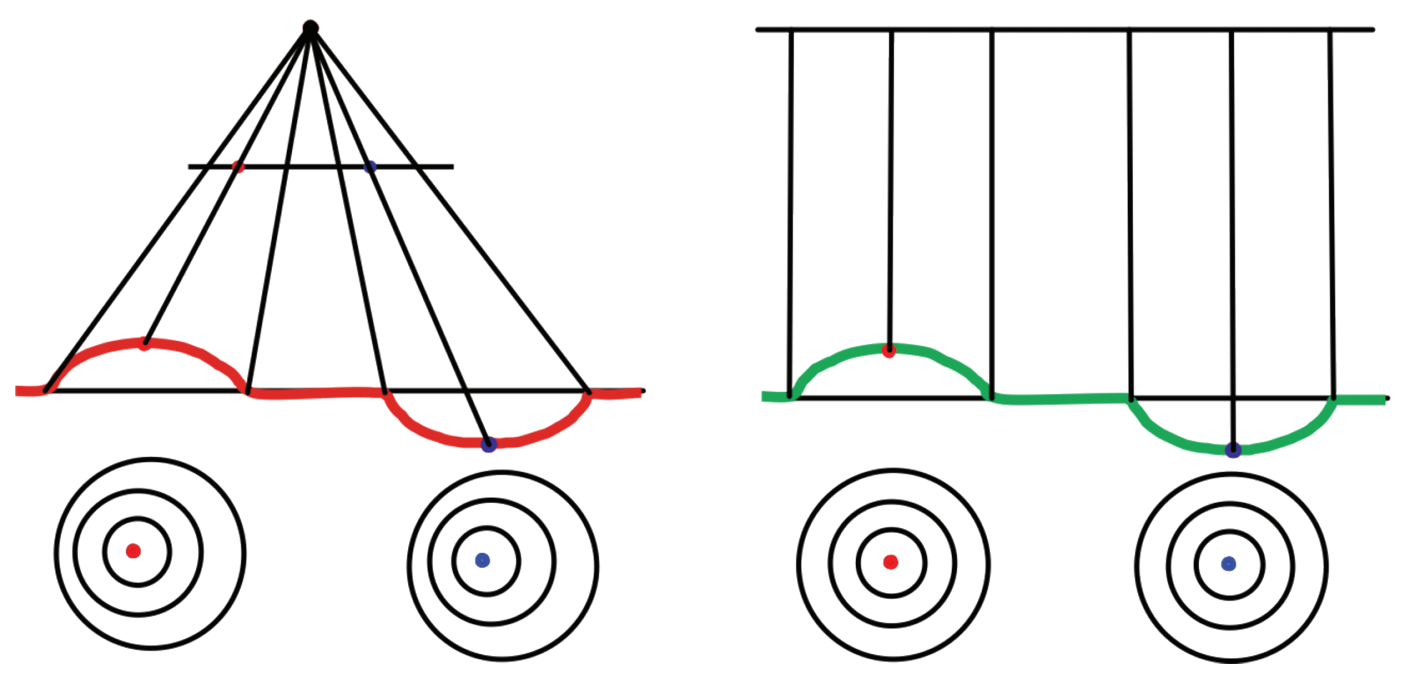

generate orthophotoplans, which are two-dimensional floor plans, cross-sections and elevation

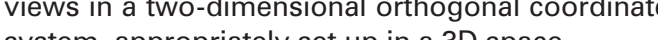

source images (photogrammetric images), whose goal is obtaining an image that would be created through orthogonal projection onto a reference Wrips and projection onto a surface. In other wection is the replacement of a perspective proremoving the distortion of source im is based on tion to the final image presented using two-dimen sional projection. ${ }^{7}$

THE VIRTUAL MODEL OF THE BUILDING

A virtual model of the building is built on the basis And linked with a lata. It can be parameterised is initially based on separating distinct parts the building (walls, floor slabs, beams, windows, doors, etc.) and assigning physical properties to each of the building's elements (brick walls, timber

Coung a vitual model of a building using a poin intensive ond from the most costly stage, however, the quality and usefulness of a 3D model in further design work is completely incomparable to that of traditional docu-

the burvey of the building of the chicAD $v 21$, modelling was performed in Arsurvey is integrated with the model of the building during the design stage - design work is performed on the same file with the virtual model of the building. The Renovation module of the program makes thossible to assign existing / demolished / newly the virtua the the the desing either in the extant or the designed phase, or apply different graphica symbosig to that should be demolished or remodelled. 

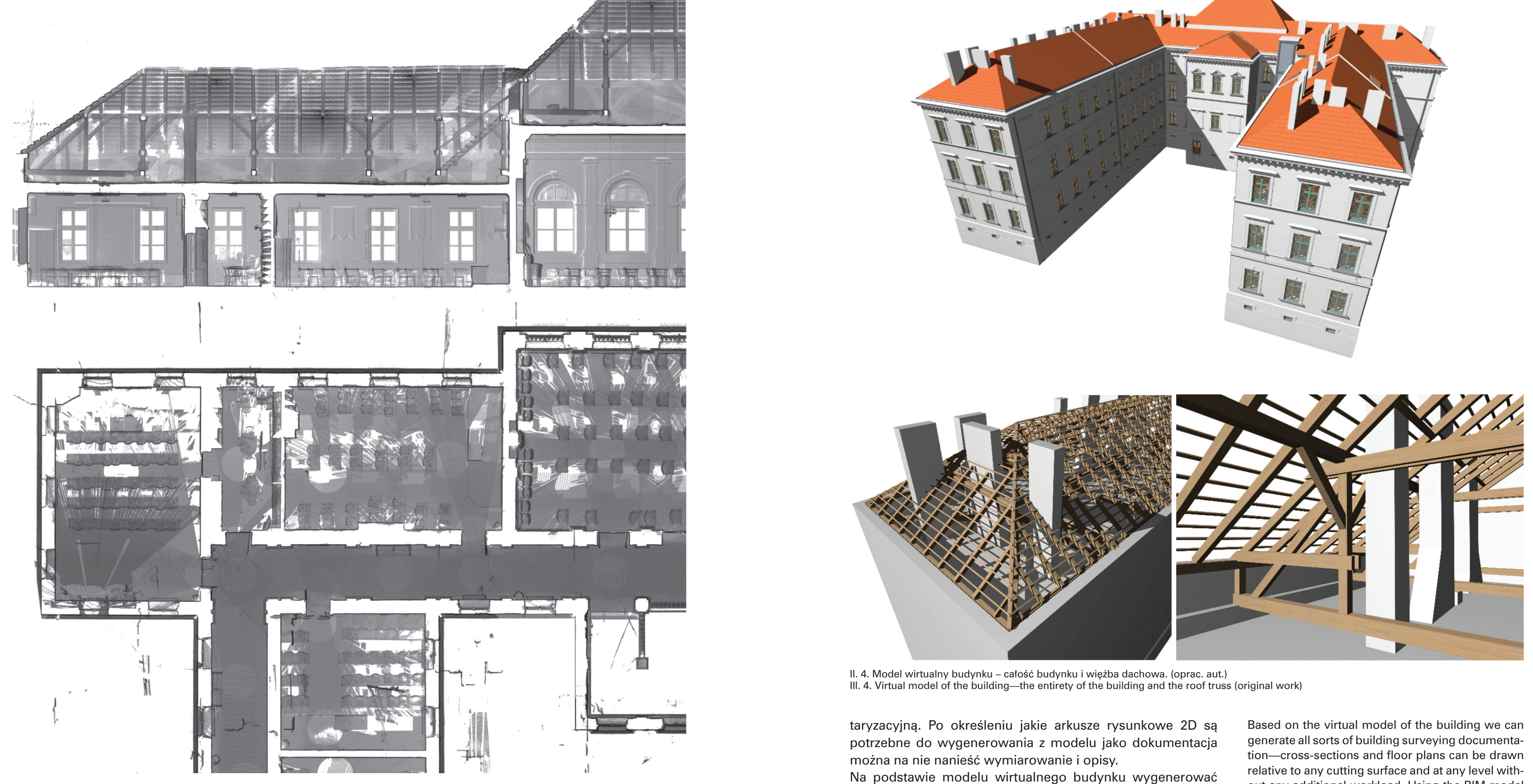

II. 4. Model wirtualny budynku - catość budynku i więzba dachowa. (oprac. aut.)
III. 4 . Virtual model of the building-the entirety of the building and the roof truss (original work)

taryzacyjną. Po określeniu jakie arkusze rysunkowe 2D sa potrzebne do wygenerowania z modelu jako dokumentacja można na nie nanieść wymiarowanie i opisy.

na podstawie modelu wirtulnego budynku wygenerowac ma podawien można dowolny zakres d́ przekroje i rzuty mogą byc bez dodalkowego nakladu pracy poprowadzo $Z$ wod poziomach z modew BIM mozemy otzymachie dy ko zestaw płaskich rysunków 2D, odpowiadających tradycyjnemu zakre-

kcie, niezbędną do dalszych prac remontowych, konserwatorskich czy projektowych

spójną i dokładną dokumentację techniczn

dowolne rysunki techniczne (rzuty na dowolnych poziomach, przekroje w dowolnych miejscach, elewacje zewnętrzne i wewnętrzne)

zestawienia ilościowe: pomieszczeń, stolarki, innych elementów budynku

różnego typu analizy, jak np. analiza nasłonecznienia, konstrukcyjna, itp.
Based on the virtual model of the building we can generate all sorts of building surveying documentation-cross-sections and floor plans can be drawrelative to any cutting surface and at any level without any additional workload. Using the BlM model correspond with the traditional scope of a building survey, but also:

A database of information about the structure, - A desery for further renovation, conservation or design work,

A cohesive and precise technical documenta-

- All sorts of technical drawings (floor plans for any and all levels, cross-sections through any area, external and internal elevations.

- Quantitative schedules of. rooms, windows and doors, other elements of the building,

Various types of analyses, such as: an insolation - A bill of quantities and a bill of.,

- All sorts of perspective and axonometric views, virtual walks, visualisations and animations.
Po wymodelowaniu przestrzennego, wirtualnego modelu budynku można zacząć kompletować dokumentację inwen- ing survey docan start completing the build2D drawing sheets should be generated from the aply dimensioning and annotation to them. 
- przedmiar i kosztorys robót

iksonometrie, spacery wirtualne, wizualizacje i animacje

PORÓWNANIE INWENTARYZACJI W STANDARDZIE BIM INWENTARYZACJA TRADYCYJNA W TECHNOLOGII CAD 2D

Większość obiektów posiada dokumentację techniczną zarchiwizowaną $w$ formie płaskich rysunków lub plików w formacie Autocad 2D. Dostęp do nich jest jednak tylko pozornie ułatwieniem i przyspieszeniem pracy. W pewnych przypadkach, możliwe jest podjęcie próby wykonania wirtualnego modelu na podstawie takich archiwalnych materiałów. Nie ma jednak pewności, że sporządzona niegdyś dokumentacja jest w pełni aktualna, a nieprawdziwe informacje, które $w$ ten sposób mogłyby sie znaleźć równiez w modelu BIM istniejącego budynku, moga prowadzić do błędów projektowych przy przebudowie czy renowacji, które zazwyczaj narażaja inwestora na nieplanowane koszty $w$ trakcie realizacji inwestycji.

Budynek jednego z krakowskich Liceów Ogólnokształcących był zinwentaryzowany w tradycyjny sposób 10 lat temu. Inwentaryzacja dotyczyla tylko jednego skrzydia bocznego na całej wysokości budynku i była następnie wykorzystana do wykonania projektu windy zewnętrznej dla osób niepełnosprawnych. Inwentaryzacja była wykonana w postaci płaskich rzutów, przekrojów i elewacji w formacie programu AUTOCAD 2D. Pliki Autocada, można zaimportowac do programu Archicad jako tzw. niezależne obszary 2D. Dzięki temu możliwe jest porownanie inwentaryzacji tradycyjnej z nowoczesna inwentaryzacją BIM, poprzez nałożenie rysunków płaskich na rzuty i przekroje, wygenerowane z modelu przestrzennego budynku wirtualnego.

Porównanie inwentaryzacji tradycyjnej z inwentaryzacja BIM w oparciu o chmure punktów wykazało niedokładności tej pierwszej w zakresie $10-30 \mathrm{~cm}$ w obrebie tylko jednego skrzydta budynku (I). Pomimo poprawnego pomiaru pomieszczeń niedoktadności narastaty przede wszystkim ze wzgledu na bledy w oszacrwatu

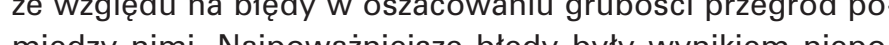
prewnej orientail budynku wzgledem osnowy geodezoprawnej orienacji budynu względem osnowy geodezyjnej i przyęcia blędnych kąow womiędzy glówylni skrzydlami mapy kondygnaci pozwata is bardzo szybka weryflacje mapy kondygnacji pozwalało na bardzo szybką weryfikację
i określenie skali błẹdów.

\section{PODSUMOWANIE}

Aktualny rozwój technologiczny, odnoszący się do większości branż wpływających na codzienne funkcjonowanie człowieka sprawia, że pojawiają się coraz nowsze rozwiązania i udoskonalenia dotychczas stosowanych systemów. Podobna sytuacja ma miejsce rowniez $w$ branzy architektury i budownictwa gdzie wzrasta udział rozwiązan informatycznych, mających na celu podniesienie jakosci projektowania budynkow oraz udostępniania informacji o ich parametrach zarówno projektantom jak i inwestorom. Korzyści płynące $z$ wdrażania technologii BIM w nowoczesnym budownictwie wydają się oczywiste. COMPARISON OF A BIM-STANDARD BUILD-
ING SURVEY WITH A TRADITIONAL BUILDING SURVEY USING 2D CAD TECHNOLOGY

Most structures possess technical documentatio drawings or files in 2D AutoCAD format. Howeve, access to such files makes work easier and quicker only apparently. In some cases it is possible to make an attempt at creating a virtual model on the basis of such archival materials. However, there is no certainty that the documentation that was prepared a that could thus also find its way into the BIM mode of the existing building can lead to design mistakes in the case of remodelling or renovation, whic usually put the developer at risk of unplanned costs during the carrying out of a project.

The building of one of Krakow's high schools was surveyed 10 years ago using the traditional method. The building survey only covered a single side wing sequently used to developed a design of an externa elevator for disabled persons. The building survey was prepared in the form of two-dimensional floo plans, cross-sections and elevations in 2D AutoCAD software format. AutoCAD files can be imported into ArchicAD as so-called independent $2 \mathrm{D}$ areas. This survey with a modern BIM building survey, by laying the two-dimensional drawings over the floor plans and cross-sections generated from the three-dimensional virtual model of the building.

The comparison of the traditional building survey with a BIM building survey prepared on the basis mer to a degree of $10-30 \mathrm{~cm}$ within only a single wing of the building (!). Despite the sufficiently correct measurement of the rooms, the errors stacked primarily due to mistakes in assessing the thicknesses of the partitions between them. The most serious mistakes were the result of the inap propriate orientation of the building in relation to gles between the main wings of the building. Laying the $2 \mathrm{D}$ CAD drawing and the orthophotoma of the level on top of each other made it possible to perform a very quick verification and assessof the scale of the errors.

\section{CONCLUSION}

gical development, which refers to loning of man, causes newer and newer solution and improvements to currently used systems to appear. A similar situation also takes place in architecture and construction, where the share of informa fin-technology-related solutions that are meant to sharing information on their parameters with both designers and developers is taking place. The benefits that can be obtained by implementing BIM technology in modern construction appear to be obvious. Advanced IT solutions enable effective cooperation between designers and the design documentation that is prepared because of it, taking into considerof the solutions that it contains. BIM technology is unavoidably becoming the standard of modern design.
Zaawansowane rozwiązania informatyczne umożliwiaja nim opracowania projektowe, uwzgleddniające najgrobniejsze szczegóły zapewniaja wysoka jakość zastosowanyc rozwiazzan. Technologia BIM nieuchronnie staje się standardem nowoczesnego projektowania.

W przypadku wykonywania inwentaryzacji technologia BIM sprawia, że opracowania projektowe sa nie sa tylko zestawem linii, wypetnién czy powierzchni, ale równiez

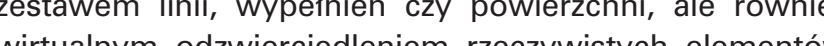
Widy W wy budy W wriku przeprowadzenia pomianow poprzez nych wormacie we i opracownie pozskanch damon w for model inwentaryzowanego obiektu, kóny sklada się nie te z $z$ szeregu dodatkowych infor lyc takie z szergu dod styczną cechą technologii BIM jest ciąglośc wykorzystania informacji generowanych na poszczegolnych etapach pracy. W BIM najważniejsza jest informacja i jej prawidłowe odpowiednie zaplanowan strategii i metodologii pracy.

PRZYPISY

BIM Curriculum, Graphisoft, 2013, [@:] http:///www.graphisoft.com/learning/training-materials/bim-curriculum/[ [dostepp: 21.03 .2016 ]
2 Tomana A., BM. Innowacyina technologia w budownictwie - podstaw/

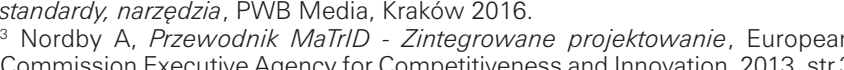
${ }_{2}^{4}[\mathrm{Q}:]$ https: 21.05 .2018$]$.

[@:] https://www.faro.com/pl-pl/produkty/budownictwo-bim-cim/faro-fo-
cus/ [dostęp: 21.05.2018]. [ [@:] http:///poiformat.pl/service/chmura-punktow/ [dostep: 21.05.2018].

LITERATURA

[1] BIM Curriculum, Graphisoft, 2013, [@:] http://Www.graphisoft.com/lear-
ning/training-materials/bim-curriculum/ [dostęp: 21.03.2016] ning/training-materials/sibim-curriculum/ [dostep: 21.03.2016]
[2] Sydor M.: Wprowadzenie do CAD. Podstawy kompterowo wspomagane go projektowania, Wydawnictwo Naukowe PWN, Warszawa 2009 (3) Nordby A, Przewodnik MatriD - Zintegrowane projektowanie, European

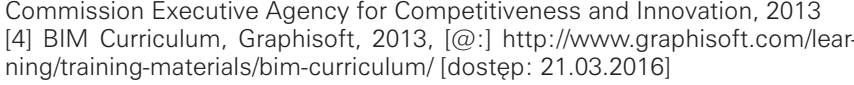
ning/training-materialss/bim-curriculum/ /dostep: 21.03.2016]
[5] Markiewicz P., integrowane Projektowanie Energetyczne jednorodzin-

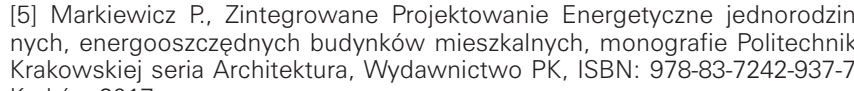

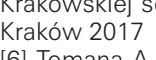

[6] Tomana A. BIM. Innowacyina technologia w budownictwie - podstaw [7] [@:], httres://lencyklopedia.pwn.pl/haslo/tachimetria; 3984805.html [do[8] [@:] https://www.faro.com/pl-p//produkty/budownictwo-bim-cim/faro[ocus/ [dostep: 21.05.2018].

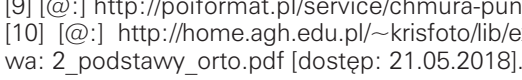

In the case of performing building surveys, BIM technology causes design documentation to become n only a set of lines, hatches or surfaces, but also a viring. As a result of the measurements performed by laser scanning and processing the data obtained in this manner in a vector format, a parametric model of the surveyed building is created, which is composed of not only the three-dimensional representation of the elements of the structure, but also of an entire array of additional information. One distinct quality of information generated during the successive stages of work. In BIM, the most important element is information and its appropriate preparation and flow, which is the proper planning of the strategy and methodology of work.

ENDNOTES

'BIM Curriculum, Graphisoft, 2013, [@:] httr:///www.graphisoft.com/lear 2Tomana A., BIM. Innowacyina technologia w budownictwie podstawy, standardy, narzedzial, PWB Media, Kraków 2016.
Nordby A, Przewodrik MalriD - Zintegrowane projektowanie, and Innovation, 2013, p.3 3 . [@:] https:///ncyklopedia.pwn.p//haslo/tachimetria;3984805.
html [retrieved on: 21.05.2018.] [@:] https://Www.faro.com/pl-pl/produkty/budownictwo-bimcim/faro-focus//retrieved on: 21.05 .2018 .
[@:] http:////oiformat.pl/service/chmura-punktow/ [retrieved
on: 21.05.2018]. media=fotoct

BIBLIOGRAPHY

[1] BIM Curriculum, Graphisoft, 2013, [@:] http://Www.graphi-
soft.com/learning/training-materials/bim-curriculum/ [retrieved sydor $\mathrm{M}$.

Wspomaganego orojadzenie do CAD. Podstawy komputerowo
Warszawa 2009 , Wydawnictwo Naukowe PWN Warszawa 2009
[3] Nordby A, Przewodnin MaTrlD - Zintegrowane projektowa
nie, European Commission Executive Agency for Competitive ness and Innovation, 2013
[4] BIM Curriculum, Graphisoft, 2013, [@:] httr:///Www.graphi-
soft.com/learning/training-materials/bim-curriculum/ [retrieved on: 21.03 .2016$]$ ] $[5]$ Markiewicz P., Zintegrowane Projektowanie Energetyczne ednorodzinnnch, energoosszczednnch budynków miesskalnych monographs of the Cracow University of Technology, series:
chitektura, Wydawnictwo PK, ISBN: 978-83-7242-937-7, Krakón [6] Tomana A., BIM. Innowacyina technologia w budownictwie
- podstawy, standardy, narzędzia, PWB Media, Krakíw 2016 .

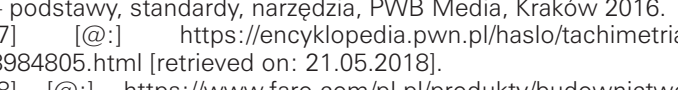

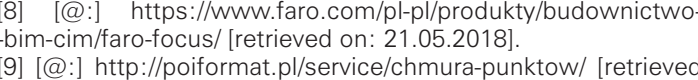

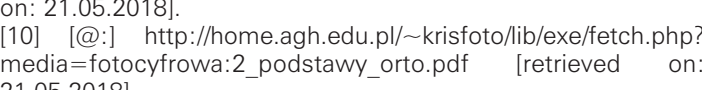

